\title{
Corrigendum: A Quantitative Assessment of Factors Affecting the Technological Development and Adoption of Companion Diagnostics
}

\author{
Dee Luo ${ }^{1}$, James A. Smith ${ }^{2,3}$, Nick A. Meadows ${ }^{4}$, Anna Schuh ${ }^{5}$, Katie E. Manescu, \\ Kim Bure ${ }^{7}$, Benjamin Davies ${ }^{8}$, Rob Horne ${ }^{9}$, Mike Kope ${ }^{10}$, David L. DiGiusto ${ }^{11}$ and \\ David A. Brindley 1, 2, 3, 12, 13, 14*
}

\begin{abstract}
1 Department of Biological Basis of Behavior, University of Pennsylvania, Philadelphia, PA, USA, ${ }^{2}$ The Oxford-University College London Centre for the Advancement of Sustainable Medical Innovation, The University of Oxford, Oxford, UK, ${ }^{3}$ Nuffield Department of Orthopaedics, Rheumatology, and Musculoskeletal Sciences, University of Oxford, Oxford, UK, ${ }^{4}$ Kinapse, London, UK, ${ }^{5}$ Oxford National Institute of Health Research, Biomedical Research Centre, Molecular Diagnostic Centre, Oxford University Hospitals, Oxford, UK, ${ }^{6}$ Department of Biochemical Engineering, University College London, London, UK, ${ }^{7}$ Nuffield Department of Orthopaedics, Rheumatology, and Musculoskeletal Sciences, Botnar Research Centre, University of Oxford, Oxford, UK, ${ }^{8}$ Sartorius Stedim, Göttingen, Germany, ${ }^{9}$ The UCL School of Pharmacy, University College London, London, UK, ${ }^{10}$ SENS Research Foundation, Mountainview, CA, USA, ${ }^{11}$ Stem Cell and Cellular Therapeutics Operations at Stanford University Hospital and Clinic, California, CA, USA, ${ }^{12}$ USCF-Stanford Center of Excellence in Regulatory Science and Innovation, California, CA, USA, ${ }^{13}$ Centre for Behavioural Medicine, UCL School of Pharmacy, University College London, London, UK, ${ }^{14}$ Harvard Stem Cell Institute, Cambridge, MA, USA
\end{abstract}

Keywords: companion diagnostic, combinational therapy, risk:benefit appraisal, healthcare risk management, personalized medicine, stratified medicine, healthcare translation, commercialization

\section{OPEN ACCESS}

Edited and reviewed by: Alex Zhavoronkov,

The Biogerontology Research Foundation, UK

${ }^{*}$ Correspondence: David A. Brindley david.brindley@ndorms.ox.ac.uk

Specialty section:

This article was submitted to Genetics of Aging,

a section of the journal

Frontiers in Genetics

Received: 22 April 2016 Accepted: 24 May 2016

Published: 07 June 2016

Citation:

Luo D, Smith JA, Meadows NA,

Schuh A, Manescu KE, Bure K, Davies B, Horne R, Kope M, DiGiusto

DL and Brindley DA (2016)

Corrigendum: A Quantitative Assessment of Factors Affecting the

Technological Development and Adoption of Companion Diagnostics.

Front. Genet. 7:104.

doi: 10.3389/fgene.2016.00104

\section{A corrigendum on}

A Quantitative Assessment of Factors Affecting the Technological Development and Adoption of Companion Diagnostics

by Luo, D., Smith, J. A., Meadows, N. A., Schuh, A., Manescu, K. E., Bure, K., et al. (2015). Front. Genet. 6:357. doi:10.3389/fgene.2015.00357

With regards to Figure 3: Significant relationships and non-significant relationships for CDx price, the graph (A) of CDx Price vs. CDx Sensitivity as well as the corresponding legend, is in error. Graph A wrongly depicts a trendline unadjusted for outlier effect, and the correct graph, as described in the text, is shown below. The corresponding legend has been likewise corrected to reflect the correct graph title and statistical values described in the text. This correction does not affect the scientific validity of the results, as the discrepancy was with the presentation of results.

\section{AUTHOR CONTRIBUTIONS}

All authors listed, have made substantial, direct and intellectual contribution to the work, and approved it for publication.

Conflict of Interest Statement: The authors declare that the research was conducted in the absence of any commercial or financial relationships that could be construed as a potential conflict of interest.

Copyright $\odot 2016$ Luo, Smith, Meadows, Schuh, Manescu, Bure, Davies, Horne, Kope, DiGiusto and Brindley. This is an open-access article distributed under the terms of the Creative Commons Attribution License (CC BY). The use, distribution or reproduction in other forums is permitted, provided the original author(s) or licensor are credited and that the original publication in this journal is cited, in accordance with accepted academic practice. No use, distribution or reproduction is permitted which does not comply with these terms. 
A

CDx Price vs. CDx Sensitivity

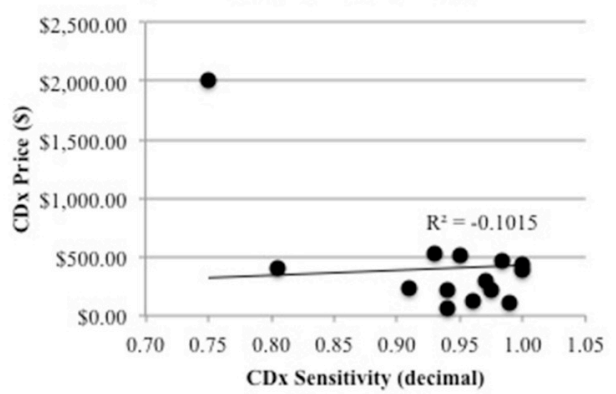

CDx Sensitivity (decimal)

C

CDx Price vs. Total Patient Population

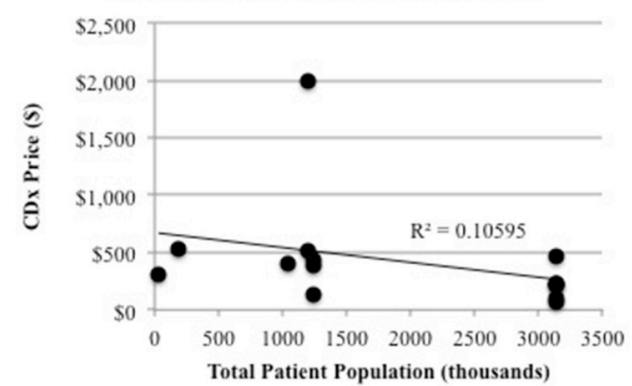

B

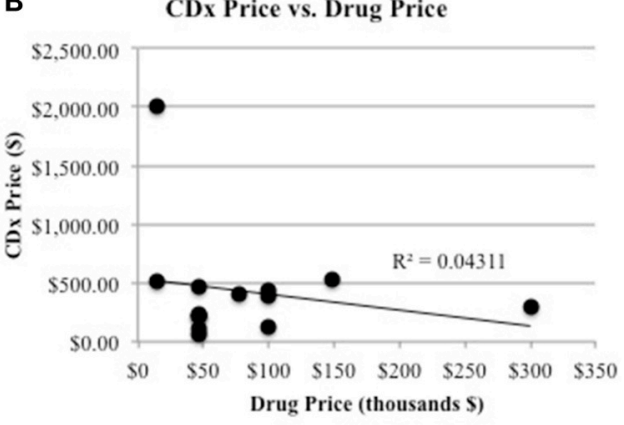

FIGURE 3 | Significant relationships and non-significant relationships for CDx price. (A) There is a significant relationship between CDx price and CDx sensitivity $\left(R^{2}=-0.10, p=0.04\right)$. (B) There are non-significant relationships between CDx price and drug price $\left(R^{2}=0.043, p=0.70\right)$ and $(\mathbf{C})$ the total patient population $\left(R^{2}=0.105 p=0.59\right)$. 